\section{Polymorphism of PIT-1 Genes and its Relationship with Traits in the Limousine Cattle Breed}

\author{
Jarosław Pytlewski ${ }^{1}$, Ireneusz R. Antkowiak ${ }^{1}$ and Ewa Czerniawska-Piątkowska ${ }^{2 *}$ \\ ${ }^{1}$ Department of Animal Breeding and Product Quality Assessment, Faculty of \\ Veterinary Medicine and Animal Science, Poznań University of Life Sciences, \\ Poznań, Poland. Złotniki, ul. Stoneczna 1, 62-002 Suchy Las. \\ ${ }^{2}$ Department of Ruminant Science, West Pomeranian University of Technology, ul. \\ Klemensa Janickiego 29, 71-270 Szczecin, Poland
}

\begin{abstract}
A B S T R A C T
The aim of the study was to analyse the polymorphism of the PIT- 1 gene withe introns 4 and 5 and exon 6 in the Limousine cattle breed and its relation to selected rearing traits. Relationships were determined between the genetic variants of the three polymorphic sites of the PIT-1 gene and the following rearing parameters: body weight at birth, body weight at weaning on day 270 , daily weight gain from birth to weaning, age at first calving and body weight after first calving. The frequency of alleles of the analysed loci was: $\mathrm{T}=0.2887$ and $\mathrm{G}=0.7913$ (IVS4-39G $>\mathrm{T}$ ), $\mathrm{A}=0.1087$ and $\mathrm{G}=0.8913$ (IVS5 $+438 \mathrm{G}>\mathrm{A}$ ) and $A=0.2913$ and $\mathrm{G}=0.7087$ (c.1178G $>A$ ). For each of the studied polymorphic sites, homozygotes $(-,-)$ were found least frequently. The results showed relationship between polymorphism in loci IVS5 $+438 \mathrm{G}>$ $A$ and c. $1178 \mathrm{G}>A$, and rearing traits. The analysis confirmed significant statistical differences $(P \leq$ $0.05)$ between homozygotes $(+,+)$ and heterozygotes $(+,-)$ for the following traits: age at first calving (IVS5 $+438 \mathrm{G}>\mathrm{A}$ ), weights at weaning $(\mathrm{c} .1178 \mathrm{G}>\mathrm{A}$ ) and daily weight gain from birth to weaning $($ c. $1178 \mathrm{G}>\mathrm{A})$. The most preferable results were found for homozygous $(+,+)$ animals. The mutation in 6 exons 6 proved particularly interesting $(\mathrm{c} .1178 \mathrm{G}>\mathrm{A})$, and the $\mathrm{GG}$ genotype was the most advantageous genetic variant.
\end{abstract}

\begin{tabular}{l} 
Article Information \\
\hline Received 16 November 2019 \\
Revised 02 January 2020 \\
Accepted 09 January 2020 \\
Available online 25 Februay 2021 \\
(early access) \\
Published 07 January 2022 \\
Authors' Contribution \\
\hline JP conceived and designed the study, \\
executed the experimental work. IRA \\
statistically analyzed the data, ECP \\
wrote the article and edited text. \\
Key words \\
\hline Limousine cattle breed, Polymorphism \\
of PIT-1 gene
\end{tabular}

\section{INTRODUCTION}

$\mathrm{P}$ tuitary transcription factor PIT-1 plays variety of roles, e.g. somatotropic, lactotropic and thyrotropic (Cohen et al., 1996; Herman et al., 2012). It is responsible for the development of the pituitary gland (Joudrey et al., 2003; Shewchuk et al., 2006; Zhang et al., 2010). Mutations in the PIT-1 gene may cause deficiency of the pituitary hormones (Li et al., 1990; Pfäffle et al., 1992). In turn, Franco et al. (2005) suggested that polymorphism of the PIT-1 gene may be used as a marker of for phenotypic traits related to the functioning of the growth hormone. According to Oprządek et al. (2004), PIT-1 in cattle is an excellent potential $Q T L$ affecting growth and composition of the carcass.

The aim of the study was to analyse polymorphism of the PIT-1 gene with introns 4 and 5 and exon 6 in the Limousine cattle breed and its relation to selected rearing traits.

\footnotetext{
* Corresponding author: ewa.czerniawska-piatkowska@zut.edu.pl

0030-9923/2022/0002-0599 \$ 9.00/0

Copyright 2022 Zoological Society of Pakistan
}

\section{MATERIALS AND METHODS}

The analysis covered 115 individuals of the Limousine female breed kept in a farm in the Wielkopolska region (Poland). The animals were kept in the loose housing system without free access to the pasture. The diet was balanced according to the INRA system. In order to determine gene polymorphism of the selected PIT-1 loci blood samples were collected from the jugular vein. The study was based on the analysis of three polymorphic sites in the PIT-1 gene located on one chromosome. The characteristics of the polymorphic sites analysed are presented in Table I.

Table I. Characteristics of the polymorphic analytical sites in PIT-1 gene.

\begin{tabular}{llll}
\hline Gene & locus & Site of mutation & Type of mutation \\
\hline PIT-1 & IVS4-39G $>$ T & Intron 4 & $\mathrm{G} \rightarrow \mathrm{T}$ \\
& IVS5+438g $>$ A & Intron 5 & $\mathrm{G} \rightarrow \mathrm{A}$ \\
& c.1178G $>\mathrm{A}$ & Exon 6 & $\mathrm{G} \rightarrow \mathrm{A}$ \\
\hline
\end{tabular}


Table II. Primer sequences for amplification of fragment of PIT-1 gene fragments.

\begin{tabular}{llll}
\hline Gene & Primer & PCR primer sequences $\left(\mathbf{5}^{\prime}\right.$ - 3') & Source material \\
\hline PIT-1 & PIT-114F & 5'-AGGATACACCCAGACAAATG - 3' & Zhao et al. (2004) \\
& PIT-114R & 5'- TACTGATTGTTGTTCTCCGT - 3' & \\
& PIT-115F & 5'- TCCTTCTCCAGGAGATCTTCC - 3' & This study \\
& PIT-115R & 5'-GTCCCCCAGAACTCAGGTTAT - 3' & \\
& PIT-1E6F & 5'-AAACCATCATCTCCCTTCTT - 3' & Wollard et al. (1994) \\
& PIT-1E6R & 5'-AATGTACAATGTCCTTCTGAG - 3' & \\
\hline
\end{tabular}

Isolation of genetic material

DNA was isolated from peripheral blood made by the phenol method (Sambrook et al., 1989).

\section{PCR amplification of the PIT-1 gene}

The DNA fragment of interest was amplified in a TGradient thermocycler (Biometria) using primer sequences as shown in the Table II.

The reaction mixture in a volume of $15 \mu 1$ contained: $100 \mathrm{ng}$ genomic DNA, $0.6 \mathrm{U}$ Taq polymerase, $10 \mathrm{pmol}$ of each primer, $1.5 \mathrm{mM} \mathrm{MgCl}_{2}, 200 \mu \mathrm{M}$ dNTPs, $1.5 \mu 1$ PCR buffer - $\left(\mathrm{NH}_{4}\right)_{2} \mathrm{SO}_{4}(10 \mathrm{x})$ and $0.75 \mu 1$ DMSO.

The thermal cycle comprised initial denaturation for loci IVS4 - 39G $>$ T, IVS5 $+438 \mathrm{~g}>\mathrm{A}$ and c. $1178 \mathrm{G}>\mathrm{A}$ of $97{ }^{\circ} \mathrm{C}, 94^{\circ} \mathrm{C}$ and $95^{\circ} \mathrm{C}$, respectively, for $300 \mathrm{sec}$. -It was followed by, 30 cycles of denaturation (IVS4-39G $>\mathrm{T}, 95^{\circ} \mathrm{C} / 30 \mathrm{~s}$, IVS5+438G $>\mathrm{A}, 94^{\circ} \mathrm{C} / 30 \mathrm{~s}$ and c. $1178 \mathrm{G}>\mathrm{A}, 95^{\circ} \mathrm{C} / 30 \mathrm{~s}$ ), annealing (IVS4-39G $>\mathrm{T} ; 58.2$ ${ }^{\circ} \mathrm{C} / 30 \mathrm{~s}$, IVS5 + $438 \mathrm{G}>\mathrm{A} ; 59{ }^{\circ} \mathrm{C} / 30 \mathrm{~s}$ and c. $1178 \mathrm{G}>A$; $\left.51{ }^{\circ} \mathrm{C} / 30 \mathrm{~s}\right)$ and extension $\left(72{ }^{\circ} \mathrm{C} / 50 \mathrm{~s}\right)$, followed by final elongation $\left(72{ }^{\circ} \mathrm{C} / 300 \mathrm{~s}\right)$.

The amplification products were digested in a restriction enzyme buffer at a specific temperature using a buffer for $3 \mathrm{~h}$. For locus IVS4-39G $>\mathrm{T}$ the restriction $M v a \mathrm{I}$ enzyme in the $\mathrm{R}$ buffer was used, the reaction temperature was $37{ }^{\circ} \mathrm{C}$. For locus IVS5+438g $>$ A the TaqI, TaqI buffer was used at process temperature of $65^{\circ} \mathrm{C}$. For locus c. $1178 \mathrm{G}>\mathrm{A}$ is the $\operatorname{Hinf} \mathrm{I}$ enzyme in the $\mathrm{R}$ buffer was used at the reaction temperature of $37^{\circ} \mathrm{C}$. The composition of the reaction mixture $(11 \mu \mathrm{l})$ per sample was as follows: $5 \mu 1$ of the PCR product, $1 \mu 1$ of the respective restriction enzyme at a concentration of $10 \mathrm{U} /$ $\mu \mathrm{l}$ (Fermentas), $1 \mu \mathrm{l}$ enzyme buffer (Fermentas) and $4 \mu \mathrm{l}$ $\mathrm{H}_{2} \mathrm{O}$.

After restriction enzyme digestion of each sample the reaction mixture was supplemented with $2 \mu$ lof loading buffer $\mu$-gel loading solution type I, 6x. Afterwards the digestion products were identified by electrophoresis in a 3\% agarose gel (BASICA GQT, Prona) in $1 \times$ TBE buffer. The Gene Ruler DNA Ladder Mix was used to a mixture consisting of $2 \mu \mathrm{l}$ of the loading buffer, $1.5 \mu \mathrm{l}$ of the DNA marker and $10.5 \mu 1$ of $\mathrm{H} 2 \mathrm{O}$. Loci IVS4-39G $>\mathrm{T}$, IVS5 $+438 \mathrm{G}>\mathrm{A}$ and c. $1178 \mathrm{G}>\mathrm{A}$, the-electrophoresis time and the voltage applied were $55 \mathrm{~min}$ and $150 \mathrm{~V}, 45 \mathrm{~min}$ and $150 \mathrm{~V}, 35 \mathrm{~min}$ and $140 \mathrm{~V}$, respectively. The digestion products were examined under UV light.

\section{Identification of genotypes}

The amplified fragments of the PIT- 1 gene were 980 bp (IVS4-39G $>$ T), 302 bp (IVS5 + 438G $>$ A) and 451 bp (c.1178G $>$ A). Next the genotypes were identified:

-locus IVS4-39G $>$ T; TT (-,-) - 980 bp (un recognised by the restriction enzyme), GT (-,+) - fragments of 104 bp, $876 \mathrm{bp}$ and $980 \mathrm{bp}$ and $\mathrm{GG}(+,+)$ fragments of $104 \mathrm{bp}$ and $876 \mathrm{bp}$,

-locus IVS5+438G $>$ A; AA (-,-) - 302 bp (un recognised by the restriction enzyme), AG $(-,+)$ fragments of $21 \mathrm{bp}, 281 \mathrm{bp}$ and $302 \mathrm{bp}$ and $\mathrm{GG}(+,+)$ - fragments of $21 \mathrm{bp}$ and $281 \mathrm{bp}$,

-locus c.1178G $>\mathrm{A}$; AA (-,-) - 451 bp (un recognised by the restriction enzyme), AG (-,+) - fragments of 207 bp, $244 \mathrm{bp}$ and $451 \mathrm{bp}$ and $\mathrm{GG}(+,+)$ - fragments of $207 \mathrm{bp}$ and $244 \mathrm{bp}$.

\section{Statistical analysis}

A detailed analysis of the results was based on the following calculations: the actual and theoretical frequency of genotypes, gene frequency and the observed and expected number of individuals for general gene polymorphisms according to the Hardy-Weinberg equilibrium. The $\chi^{2}$ test was applied in the statistical calculations.

The study investigated the relationship between genetic variants of the three polymorphic PIT-1 genes and selected rearing parameters for females. The following rearing traits were analysed: body weight at birth $(\mathrm{kg})$, body weight at weaning at 270 days $(\mathrm{kg})$, daily weight gain from birth to weaning ( $\mathrm{g}$ ), age at the first calving (days) and body weight after first calving ( $\mathrm{kg}$ ). Due to the small number of homozygotes (-,-) and the lack of complete source information necessary to estimate the 
relationship between polymorphism of the PIT-1 gene and breeding parameters data from heterozygotes $(+,-)$ and homozygotes $(+,+)$ were used in statistical calculations for each locus. The statistical calculations were conducted using the SAS® (2013) statistical package applying the. MEANS and GLM procedures. The significance of the effect of experimental factors on the studied rearing traits was estimated using a multivariate covariance analysis according to the following linear model:

$Y_{i j k l m n o p}=\mu+g_{i}+y_{j}+s_{k}+f_{l}+$ PIT-1I4 ${ }_{m}+$ PIT-1I5 ${ }_{n}+$ PIT-1E6 $+e_{\text {ijklmnop }}$

where $\mathrm{Y}_{\mathrm{ijklmnop}}$ is the phenotypic value of the analysed trait; $\mu$ is population average, $g_{i}$ is fixed effect of the share of Limousine genes $(i=1, . ., 2) ; y_{j}$ is the fixed effect of the calving year $(\mathrm{j}=1, . ., 5) ; \mathrm{s}_{\mathrm{k}}$ is fixed effect of the calving season $(\mathrm{k}=1, \ldots, 4)$; $\mathrm{f}_{1}$ is fixed effect of the sire $(1=1, \ldots, 26)$; PIT is $1 \mathrm{I} 4_{\mathrm{m}}$ - fixed effect of genotype locus IVS4-39G> $\mathrm{T}(\mathrm{m}=1,2)$; PIT is $1 \mathrm{I} 5_{\mathrm{n}}$ - fixed effect of genotype locus IVS5 + 438G $>$ A $(n=1,2)$; PIT-1E6 - fixed effect of genotype locus c.1178G $>$ A $(\mathrm{o}=1,2,)^{2}$ and $\mathrm{e}_{\mathrm{ijklmnop}}$ is random error.

Table III. Frequency of alleles in locus IVS4-39G $>$ T and also the actual and theoretical distribution of genotypes as well as the observed and expected number of individuals in studied population of cows.

\begin{tabular}{lllll}
\hline Traits & \multicolumn{4}{c}{ Locus IVS4-39G>T } \\
\cline { 2 - 5 } & \multicolumn{3}{c}{ Genotype } & GG \\
\cline { 2 - 5 } & TT & 46 & 68 & 115 \\
\hline Observed number of cows & 1 & 38 & 72 & 115 \\
Theoretical number of cows & 5 & 0,4000 & 0,5913 & 1,000 \\
Actual frequency of genotypes & 0,0087 & 0,3303 & 0,6261 & 1,000 \\
Theoretical frequency of genotypes & 0,0436 & 1,6923 & 0,2232 & 5,1238 \\
$\chi^{2}$ & 3,2083 & & $\mathrm{G}=0,7913$ & 1,000 \\
Frequency of alleles & $\mathrm{T}=0,2087$ & & & \\
\hline
\end{tabular}

**, $\mathrm{P} \leq 0,01 ; *, \mathrm{P} \leq 0,05$

Table IV. Frequency of alleles in locus IVS5+438G $>A$ and also the actual and theoretical distribution of genotypes as well as the observed and expected number of individuals in studied population of cows.

\begin{tabular}{|c|c|c|c|c|}
\hline \multirow[t]{3}{*}{ Traits } & \multicolumn{4}{|c|}{ Locus IVS5+438G $>A$} \\
\hline & \multicolumn{3}{|c|}{ Genotype } & \multirow[t]{2}{*}{$\sum$} \\
\hline & $\mathbf{A A}$ & AG & GG & \\
\hline Observed number of cows & 2 & 21 & 92 & 115 \\
\hline Theoretical number of cows & 1 & 22 & 91 & 115 \\
\hline Actual frequency of genotypes & 0,0174 & 0,1826 & 0,800 & 1,000 \\
\hline Theoretical frequency of genotypes & 0,0118 & 0,1938 & 0,7944 & 1,000 \\
\hline$\chi^{2}$ & 0,3027 & 0,0738 & 0,0045 & 0,3810 \\
\hline Frequency of alleles & $A=0,1087$ & $\mathrm{G}=0,8913$ & & 1,000 \\
\hline
\end{tabular}

A detailed comparison of the object-oriented means was carried out using the Duncan multiple range test.

\section{RESULTS}

Tables III, IV and $\mathrm{V}$ contain the results regarding the frequency of alleles and the actual and theoretical distribution of genotypes at IVS4-39G $>$ T, IVS5+438G $>$ A and c. $1178 \mathrm{G}>\mathrm{A}$, respectively, and the observed and expected number of individuals in the studied population of Limousine cows. It was shown that the frequency of alleles in the analysed loci was: $\mathrm{T}=0.2087$ and $\mathrm{G}=0.7913$ (IVS4$39 \mathrm{G}>\mathrm{T}$ ), $\mathrm{A}=0.1087$ and $\mathrm{G}=0.8913$ (IVS5+438G $>\mathrm{A}$ ), $\mathrm{A}=$ 0.2913 and $\mathrm{G}=0.7087$ (c. $1178 \mathrm{G}>\mathrm{A}$ ).

In the investigated group of cows, the lowest number of homozygotes were found as undigested 39G $>$ T), AA (IVS5+438G $>$ A) and AA (c.1178G $>$ A). The studied population of the Limousine cattle was found to reach the genetic equilibrium. with the restriction enzymes (-,-): TT (IVS4-

**, $\mathrm{P} \leq 0,01 ; *, \mathrm{P} \leq 0,05$ 
Table V. Frequency of alleles in locus c.1178G $>A$ and also the actual and theoretical distribution of genotypes as well as the observed and expected number of individuals in studied population of cows.

\begin{tabular}{lllll}
\hline Traits & \multicolumn{3}{c}{ Locus c.1178G $>$ A } \\
\cline { 2 - 4 } & \multicolumn{3}{c}{ Genotype } & GG \\
\cline { 2 - 4 } & AA & 45 & 59 & 115 \\
\hline Observed number of cows & 11 & 47 & 58 & 115 \\
Theoretical number of cows & 10 & 0,3913 & 0,5130 & 1,000 \\
Actual frequency of genotypes & 0,0957 & 0,4129 & 0,5022 & 1,000 \\
Theoretical frequency of genotypes & 0,0849 & 0,1298 & 0,0267 & 0,3144 \\
$\chi^{2}$ & 0,1579 & $\mathrm{G}=0,7087$ & 1,000 \\
Frequency of alleles & $\mathrm{A}=0,2913$ & & & \\
\hline
\end{tabular}

**, $\mathrm{P} \leq 0.01 ; *, \mathrm{P} \leq 0.05$

Table VI. Selected rearing traits of Limousine females depending on the genotype genotype at loci IVS439G $>$ T. IVS5+438G $>A$ and c.1178G $>A$.

\begin{tabular}{llcccccc}
\hline Locus & $\begin{array}{l}\text { Geno- } \\
\text { type }\end{array}$ & $\mathbf{N}$ & \multicolumn{5}{c}{ Traits } \\
\cline { 3 - 8 } & & & $\begin{array}{l}\text { Body weight } \\
\text { at birth (kg) }\end{array}$ & $\begin{array}{l}\text { Body weight at } \\
\text { weaning (kg) }\end{array}$ & $\begin{array}{l}\text { Daily weight gain from } \\
\text { birth to weaning (g) }\end{array}$ & $\begin{array}{l}\text { Age at first } \\
\text { calving (days) }\end{array}$ & $\begin{array}{l}\text { Body weight at } \\
\text { first calving (kg) }\end{array}$ \\
\cline { 3 - 8 } & & Mean \pm SD & Mean \pm SD & Mean \pm SD & Mean \pm SD & Mean \pm SD \\
\hline IVS4-39G $>$ T & GT & 46 & $36.5 \pm 2.6$ & $229.4 \pm 12.6$ & $935 \pm 95$ & $959 \pm 118$ & $537.3 \pm 38.5$ \\
& GG & 68 & $35.8 \pm 3.2$ & $243.3 \pm 22.4$ & $982 \pm 107$ & $992 \pm 117$ & $541.3 \pm 30.4$ \\
IVS5+438G>A & AG & 21 & $34.7 \pm 3.6$ & $229.0 \pm 16.6$ & $957 \pm 114$ & $1031 \pm 113 \mathrm{a}$ & $530.5 \pm 51.4$ \\
& GG & 92 & $36.4 \pm 2.6$ & $238.0 \pm 19.6$ & $964 \pm 94$ & $972 \pm 118 \mathrm{~b}$ & $541.0 \pm 55.2$ \\
c.1178G $>$ A & AG & 45 & $35.4 \pm 3.5$ & $228.4 \pm 15.9 \mathrm{a}$ & $916 \pm 88 \mathrm{a}$ & $994 \pm 130$ & $540.2 \pm 58.4$ \\
& GG & 59 & $36.5 \pm 2.5$ & $249.5 \pm 16.9 \mathrm{~b}$ & $1029 \pm 83 \mathrm{~b}$ & $981 \pm 108$ & $534.2 \pm 68.3$ \\
\hline
\end{tabular}

a. $b$, values in a column with different letters differ significantly $(\mathrm{P} \leq 0.05)$.

Table VI presents selected rearing traits of Limousine females taking into account their genotype in loci IVS4$39 \mathrm{G}>\mathrm{T}$, IVS5+438G $>\mathrm{A}$ and c.1178G $>$ A. The analysis showed statisticallysignificantdifferences $(\mathrm{P} \leq 0.05)$ between homozygotes $(+,+)$ and heterozygotes $(+,-)$ for the following traits: age at the first calving (locus) IVS5+438G $>$ A), body weight at weaning (locus c.1178G $>$ A) and daily weight gain from birth to weaning (c.1178G $>$ A). It was found that for the traits mentioned above within the specified loci the most advantageous results were obtained for homozygotes $(+,+)$. A younger age at first calving was recorded for the GG animals (IVS5 $+438 \mathrm{G}>\mathrm{A}$ ). A greater body weigh at weaning and a higher daily weight gain in the period from birth to weaning were found for animals with the GG genotype locus c.1178G $>$ A.

\section{DISCUSSION}

Mutations of the PIT-1 gene in introns
4 and 5 and exon 6 were studied in Angus cattle by Zhao et al. (2004). In the case of a locus IVS4-39G $>\mathrm{T}$ a higher share $(0.47$ and 0.12$)$ was found for heterozygotes $(+,-)$ and homozygotes $(-,-)$, at a lower share $(0.41)$ of homozygotes $(+,+)$ compared to the results obtained in this study. When analysing mutations in intron 5 those authors found no homozygous individuals (-,-), while the frequency of homozygotes $(+,+)$ was 0.91 . In contrast, a similar frequency of alleles for the polymorphic site of the PIT-1 gene located in the same intron was reported in cattle of four Chinese breeds and the Holstein breed by Yang et al. (2011).

For locus c.1178G $>$ A Zhao et al. (2004) showed a similar frequency $(0.44$ and 0.45$)$ of the genotypes for heterozygotes $(+,-)$ and homozygotes $(+,+)$. In a study of Dybus et al. (2003) conducted on Limousine cows the frequency of the AA genotype (0.0692) and allele A (0.2731) was slightly lower compared to those in this study. Similarly, low frequencies of allele $\mathrm{A}$ in the Qinchuan (0.23), Black-and-White (0.24) and Piemontese (0.25) were 
recorded by Zhang et al. (2009), Dybus et al. (2004) and Di Stasio et al. (2002), respectively. In contrast, a very low frequency of allele A at 0.05 was found in Gyr cattle by De Mattos et al. (2004)). Similarly, a low small share of AA genetic variants $(6.93 \%)$ for this polymorphic site in beef cattle breeds originating from China was given by Li et al. (2009). In turn, a higher frequency of the allele A (0.30) in Podolica cattle was found by Selvaggi and Cataldo (2011), Xue et al. (2006) in Nanyang cattle showed the frequency of alleles $A$ and $G$ to be 0.465 and 0.535 , respectively. In contrast, in Belgian-Blu cattle the predominant-frequency of allele A (0.53) over $\mathrm{G}(0.47)$ was reported by Renaville et al. (1997a).

In their study Zhao et al. (2004) found no relationship between the polymorphism of the PIT-1 gene in the region from intron 2 to exon 6 and growth and carcass traits in Angus cattle. Similarly, in Limousine cows Dybus et al. (2003) showed no significant dependencies between genotypes at locus c.1178G $>\mathrm{A}$, and height at the withers, height at sacrum and girth circumference at 3,210 and 365 days old. In that study, the authors also reported no statistically significant differences in daily gains weight from 3 to 210 and 365 days of age in animals with different genetic variant locus c.1178G $>$ A. However, Renaville et al. (1997b) found a positive relationship between the allele $\mathrm{G}$ and weight at 7 months of age in Belgian Blue bulls. Similarly, Xue et al. (2006) in Nanyang cattle showed a more beneficial influence of the GG genotype on birth weight, body weight gains up to 12 months of age as well as body length and circumference in animals at 6 and 12 months of age. Those authors suggested that allele $G$ may play an essential role in body growth characteristics. The findings were consistent with the results given by Selvaggi et al. (2011) for the Podolica breed and and Yang et al. (2011) who were looking for a gene responsible for growth traits in Chinese cattle breeds. In turn, Zhang et al. (2009) in the group of Germany Yellow x Qinchua hybrids in the AG heterozygote compared to the GG homozygotes found a higher body mass and greater height at the withers. In their study Oprządek et al. (2003) found that in Blackand-White cattle, the GG homozygotes consumed less feed and its components than the heterozygotes AG, while there was no statistically significant relationship between the genotypes and weight of meat, fat and bone in bulls at the age of 15 months. Oprządek et al. (2006) also showed the effect of the interaction between LEP and PIT1 genes on the performance traits of slaughtered Black-andWhite bulls. The greatest body weight before slaughter was recorded for animals with the $\mathrm{AB} \times \mathrm{GG}$ genotype and the most advantageous carcass value and concentration of fat obtained individuals genotype BB x GG. Also, the results of analyses by Sang-Hyun et al. (2010) suggested that the polymorphism of the PIT-1 gene in exon 6 may have an effect on body mass and fat content in the Hanwoo bulls.

Some studies demonstrated no association between polymorphisms in the gene PIT-1 and production traits in beef cattle (Di Stasio et al., 2002; Rogério et al., 2006; Pan et al., 2008).

\section{CONCLUSION}

The results obtained in our analyses may indicate the relationship between the PIT-1 gene polymorphism and rearing traits in Limousine cattle. In terms of body weight at weaning and daily weight gain from birth to weaning, a mutation in exon 6 (c.1178G $>$ A) proved to be particularly interesting, with the GG genotype being the most advantageous genetic variant. At the same time, the results need to be considered preliminary. To confirm these findings further research is required on a larger population of animals, taking into account a larger number of cattle breeds.

Statement of conflict of interest

The authors declare there is no conflict of interest.

\section{REFERENCES}

Cohen, L.E., Wondisford, F.E. and Radovick, S., 1996. Role of PIT-1 in gene expression of growth hormone. prolactin and thyrotropin. Endocrinol. Metab. Clin. North Am., 25: 523-540. https://doi.org/10.1016/ S0889-8529(05)70339-X

De Mattos, K.K., Del Lama, S.N., Martinez, M.L. and Freitas, A.F., 2004. Association of bGH and PIT-1 gene variants with milk production traits in dairy Gyr bulls. Pesqui Agropec. Bras., 39: 147-150. $\quad$ https://doi.org/10.1590/S0100204X2004000200007

Di Stasio, L., Sartore, S. and Albera, A., 2002. Lack of association of $\mathrm{GH} 1$ and POU1F1 gene variants with meat production traits in Piemontese cattle. Anim. Genet., 33: 61-64. https://doi.org/10.1046/j.1365-2052.2002.00811.x

Dybus, A., Kmieć, M., Sobek, Z., Pietrzyk, W. and Wiśniewski, B., 2003. Associations between polymorphisms of growth hormone releasing hormone $(G H R H)$ and pituitary transcription factor 1 (PIT1) genes and production traits of Limousine cattle. Arch. Tierz., 46: 527-534. https://doi. org/10.5194/aab-46-527-2003

Dybus, A., Szatkowska, I., Czerniawska-Piątkowska, E., Grzesiak, W., Wójcik, J., Rzewucka, E. and Zych, S., 2004. PIT1-HinfI gene polymorphism 
and its associations with milk production traits in Polish Black-and-White cattle. Arch. Tierz., 47: 557-563. https://doi.org/10.5194/aab-47-557-2004

Franco, M.M., Antunes, R.C., Oliviera, K.M., C. D. Pereira, C.D., Biase, F.H., Nunes, F.F. and Goulart L.R., 2005. Association of Pit-1 gene polymorphism with growth hormone mRNA levels in pig pituitary glands. Genet. Mol. Biol., 28: 16-21. https://doi. org/10.1590/S1415-47572005000100003

Herman, J.P., Jullien, N., Guillen, S., Enjalbert, A., Pellegrini, I. and Franc, J.L., 2012. Research resource: A genome wide study identifies new target genes for POU1F1. Mol. Endocrinol., 26: 1455-1463. https://doi.org/10.1210/me.2011-1308

Joudrey, E.M., Lechniak, D., Petrik, J. and King, W.A, 2003. Expression of growth hormone and its transcription factor. PIT-1. in early bovine development. Moth. Reprod. Dev., 64: 275-283. https://doi.org/10.1002/mrd.10237

Li, S., Crenshaw, B., Rawson, E.J., Simmons, D.M., Swanson, L.W. and Rosenfeld, M.G., 1990. Dwarf locus mutants lacking three pituitary cell types in POU-domain gene Pit-1. Nature, 347: 528-533. https://doi.org/10.1038/347528a0

Li, J., Zhang, C., Yang, Y., Jianyong Y.U., Yang, Z., Tang. M. and Yang, M., 2009. Study on polymorphisms of Pit-1 gene in improved hybrid beef cattle groups from Liupan mountain area. China Anim. Husb. Vet. Med., 36: 89-92.

Oprządek, J., Flisikowski, K., Zwierzchowski, L. and Dymnicki, E., 2003. Polymorphism at loci of leptin (LEP). Pit1 and STAT5 and their association with growth. feed conversion and carcass quality in Black-and-White bulls. Anim. Sci. Pap. Rep., 21: 135-145.

Oprządek, J., Dymnicki, E., Flisiakowski, K., Oprządek, A. and Zwierzchowski, L., 2004. An association between gene polymorphism, biochemical indicators, feed intake and carcass traits in beef cattle. Proceedings of the XII Winter school cattle breeders. 29 March - 2 April. Zakopane. Poland. pp. 67-71 (in Polish).

Oprządek, J., Dymnicki, E., Zwierzchowski, L. and Oprządek, A., 2006. Association of polymorphism of growth hormone (GH). PIT-1 and lepin (LEP) with the value of slaughter bulls breed black and white. Proceedings of Conference "The use of the latest advances in genetics. breeding beef and milk cattle". 18-20 June. Szczecin. Poland. pp. 20-27 (in Polish).

Pan, C., Lan, X., Chen, H., Guo, Y., Shu, J., Lei, C. and Wang, X., 2008. A Taq I PCR-RFLP detecting a novel SNP in exon 2 of the bovine POU1F1 gene. Bioch. Genet., 46: 424-432. https://doi. org/10.1007/s10528-008-9160-z

Pfäffle, R.W., Dimattia, G.E., Parks, J.S., Brown, M.R., Wit, J.M., Jansen, M., Van Der Nat, H., Van Den Brande, J.L., Rosenfeld, M.G. and Ingraham, H.A., 1992. Mutation of the POU - specific domain of PIT-1 and hypopituitarism without pituitary hypoplasia. Science, 21: 1118-1121. https://doi. org/10.1126/science.257.5073.1118

Renaville, R., Gengler, N., Vrech, E., Prandi, A., Massaet, S., Corradini, C., Bertozzi, C., Mortialux, F., Burnya, A. and Portetelle, D., 1997a. PIT-1 gene polymorphism. milk yield. and conformation traits for Italian Holstein-Friesian bulls. J. Dairy Sci., 80: 3431-3438. https://doi.org/10.3168/jds.S00220302(97)76319-7

Renaville, R., Gengler, N., Parmentier, I., Mortiaux, F., Massaet, S., Bertozzi, C., Burny, A. and Portetelle, D., 1997b. Pit-1 gene Hinfi RFLP and growth traits in double-muscled Belgian Blue cattle. $J$. Anim. Sci., 75: (Suppl.1). 146.

Rogério, A.C., Palmieri., D.A., Suguisawa, L., de Oliveira, H.N., Silveria, A.C. and Lopes, C., 2006. Growth and carcass traits associated with $G H 1$ / Alu I and POU1FI / Hinf I gene polymorphisms in Zebu and crossbred beef cattle. Genet. Mol. Biol., 29: 56-61. https://doi.org/10.1590/S141547572006000100012

Sambrook, J., Fritsch, E.F. and Maniatis, T., 1989. Molecular cloning: A laboratory manual. Cold Spring Harbor Laboratory Press, pp. 3-5.

Sang-Hyun, H., In-Cheol, C., Moon-Suck, K., Ha-Yeon, J., Hong-Shik, O. and Sung-Soo L., 2010. Effects of POU1F1 and GH1 genotypes on carcass traits in Hanwoo cattle. Genes Genomics, 32:105-109. https://doi.org/10.1007/s13258-009-0708-z

SAS user's guide. 2013. Statistics version 9.3. SAS Institute. Cary. NC. USA.

Selvaggi, M. and Cataldo, D., 2011. Analysis of two PIT-1 gene polymorphisms: single nucleotide polymorphisms (SNPs) distribution patterns in Podolica cattle breed. Afr. J. Biotechnol., 10: 11360-11364.

Selvaggi, M., Cataldo, D., Nornanno, G., Dambrosio, A. and Dario, M., 2011. Podolica young bulls. Analysis of two PIT-1 gene polymorphisms. Livest. Sci., 138: 308-312. https://doi.org/10.1016/j. livsci.2011.01.007

Shewchuk, B.M., Ho, Y., Liebhaber, S.A. and Cooke, N.E., 2006. A single base difference between $\mathrm{T}-1$ binding sites at the promoter and the 
hGH locus control region specifies distinct PIT-1 Conformations and functions. Mol. Cell Biol., 26: 6535-6546. https://doi.org/10.1128/MCB.0026706

Woollard, J., Schmitz, C.B., Freeman, A.E. and Tuggle, C.K., 1994. Rapid communication: Hinf polymorphism at the bovine PIT-1 locus. J. Anim. Sci., 72: 3267-3267. https://doi. org/10.2527/1994.72123267x

Xue, K.I., Chen, H., Wang, S., Cai, X., Liu, B., Zhang, C.F., Lei, C.Z., Wang, X.Z., Wang, Y.M. and Niu, H., 2006. Effect of genetic variation of the POU1F1 gene on growth traits of Nanyang cattle. Acta Gen. Sin., 33: 901-907. https://doi. org/10.1016/S0379-4172(06)60124-8

Yang, D., Tang, L., Zhu, F. and He, G., 2011. Relationship of Pit-1 polymorphism with growth traits in Chinese cattle. Proceedings 2010 International Conference on Biology. Environment and Chemistry. IPCBEE.
IACSIT Press. Singapore, 1: 225-228.

Zhang, C., Liu, B., Chen, H., Lan, X., Lei, C., Zhang, Z. and Zhang, R., 2009. Associations of a Hinf I PCRRFLP of POU1F1 gene with growth traits in Qinchuan cattle. Anim. Biotechnol., 20: 71-74. https://doi.org/10.1080/10495390802640462

Zhang, Z.I., Florez, S., Gutierrez-Hartmann, A., Martin, J.F. and Amendt, B.A., 2010. MicroRNAs regulate pituitary development. and microRNA 26b specifically targets lymphoid enhancer factor 1 (Lef1), which modulates pituitary transcription factor 1 (PIT-1) expression. J. Biol. Chem., 5: 34718-34728. https://doi.org/10.1074/jbc.M110.126441

Zhao, Q.I., Davis, M.E. and Hines, H.C., 2004. Associations of polymorphism in the PIT-1 gene with growth and carcass traits in Angus beef cattle. J. Anim. Sci., 82: 2229-2233. https://doi. org/10.2527/2004.8282229x 